Archimer, archive institutionnelle de l'Ifremer

\title{
Holocene biostratigraphy and paleoenvironmental changes in the Black Sea based on calcareous nannoplankton
}

\author{
Simona Giunta ${ }^{a *}$, Caterina Morigi ${ }^{a}$, Alessandra Negri ${ }^{a}$, \\ Francois Guichard ${ }^{b}$, Gilles Lericolais ${ }^{\mathrm{c}}$ \\ ${ }^{a}$ Dipartimento di Scienze del Mare, Università Politecnica delle Marche, 60131 Ancona, Italia \\ ${ }^{\mathrm{b}}$ LSCE/IPSL, CEA-CNRS-UVSQ, Bât 12 Av de la Terrasse , 91198 Gif-sur-Yvette cedex, France. \\ c IFREMER - Centre de Brest, Géosciences Marines - BP 70, F-29280 PLOUZANE cedex, France \\ * Corresponding author, Tel.: +39 0712204287, fax: +39 0712204650, e-mail: giunta@univpm.it
}

\begin{abstract}
In this study, detailed micropaleontological analyses were carried out on 270 samples from eight piston cores collected in the Black Sea. The primary goal was to elucidate the Late Quaternary evolution of the Black Sea, specifically to refine its biostratigraphy and to explore the Holocene paleoenvironmental changes.

Three intervals were recognized in all the cores studied, irrespective of whether they were from the basin or the shelf. These intervals are characterized, from old to young, by the spotty occurrence, the presence and the local acme of Emiliania huxleyi respectively. Moreover, the species Braarudosphaera bigelowii is, in contrast to the younger units, absent in the oldest unit. The cooccurrence of the two marine species $E$. huxleyi and B. bigelowii suggests a shift from fresh-brackish water to low-salinity marine conditions in the Black Sea. The spotty and very rare occurrence of $E$. huxleyi in the lowermost unit is reported here for the first time.

Two hypotheses are suggested: the presence of reworked specimens from Eemian outcrops, or the presence of low salinity waters also during the "lacustrine" phase of the basin. Another feature observed in almost all the cores is the presence of a multi-lamina aragonite level in the upper part of the Ecozone 3, which functions as a marker for basin-wide correlations.

The parallel study of water samples and surficial sediment assemblages demonstrates the presence of Syracosphaera lamina in the surface water samples and its absence in the sediments, suggesting dissolution in the water column. On the other hand, the occurrence of $B$. bigelowii in all cores and its near-absence in water and in recent sediment samples suggest a change in water conditions during recent times.
\end{abstract}

Keywords: calcareous nannoplankton; Black Sea; Late Quaternary; stratigraphy 


\section{Introduction}

Previous studies suggested two different theories on the temporal evolution of the shift from lacustrine waters to a marine environment during the early Holocene in the Black Sea: dramatic or gradual (Ross and Degens, 1974; Ryan et al., 1997; Görür et al., 2001, among others). This shift led to a saltier and anoxic basin and triggered the deposition of a sapropel layer. The establishment of the modern two-way exchange between the Marmara Sea and the Black Sea is documented in the deep basin sediments by deposition of coccolith ooze. A number of authors reported distinct changes in sediment supply using basinal cores (Ross and Degens, 1974; Hay et al., 1991; Arthur and Dean, 1998; Pilskaln and Pike, 2001), and identified three lithological units useful for correlations. However, the unit boundaries were based mainly on sedimentological characteristics, and the biological content played only a minor role.

Ross et al. (1970) and Ross and Degens (1974) were the first to describe these three lithologic units. Going from bottom to top, Unit 3 consists of an alternation of light and dark lutite. The transition to Unit 2 is abrupt. It is marked by a dark, microlaminated, organic-rich sapropel layer that spans the time intervals 7,000-3,300 years B.P., and 6,200-3,300 years B.P. on the basin slope. Three distinct white bands were recognized in this unit. The lowest band consists exclusively of aragonite, the intermediate band contains both the coccolithophore $B$. bigelowii and resting cysts of the dinoflagellate Peridinium trochoideum, while the uppermost is made up exclusively of the coccolithophore Emiliania huxleyi. Unit 1 is characterized by alternating light and dark microlaminae deposited during the past 3,000 years, in which the calcareous nannoplankton consists mainly of the coccolitophore species E. huxleyi.

Although these lithofacies cannot be recognized in near-shore sediments, studies demonstrated the potential of these lithological units for basinal correlations. Other authors (Hay et al., 1991; Arthur et al., 1994; Arthur and Dean, 1998) used the same lithological units, but they added new data for a better definition of these units and their boundaries, as well as a better interpretation of their depositional environments (Fig. 1). Hay et al. (1991), for instance, replaced the boundary between Units 1 and 2 of Ross and Degens (1974) by the first E. huxleyi invasion within the sapropel layer, thereby renaming the units Unit I and II. Arthur and Dean (1998) extended the scheme of Hay et al. (1991) by adding two sub-units within Unit II on the basis of color and presence of aragonite-rich laminae at the base. Subsequently, Pilskaln and Pike (2001), in their study on flocculent layers and their role in the lamination of Unit 1, used the first invasion of E. huxleyi to define the base of Unit 1 and the first deposition of organic-rich marine sediment with complete absence of $E$. huxleyi to define of Unit 2 .

In addition to lithological studies, Bukry et al. (1970) and Bukry (1974) carried out a detailed study on the calcareous nannoplankton assemblage in several Black Sea deep-sea cores and recognized for the first time three units defined solely by their characteristic coccolith contents, thereby establishing a general criterion for paleosalinity estimation. These units are: the topmost Unit 1, in which Holocene coccoliths (mainly Emiliania huxleyi) dominate and Eocene and Cretaceous reworked species are rare; Unit 2, which contains a mix of Holocene, Eocene and Cretaceous taxa in roughly comparable abundance; and Unit 3 at the base, with only Eocene and Cretaceous reworked coccolith taxa.

The major aims of our study are: (1) to refine the Holocene Black Sea stratigraphy using a detailed semiquantitative study of the calcareous nannoplankton and $A M S{ }^{14} \mathrm{C}$ dating, (2) to demonstrate the importance of this fossil group for basin-wide correlations, and (3) to reconstruct certain paleoecological and paleoenvironmental conditions by a comparison of the fossil record with the modern calcareous nannoplankton distribution in the basin.

\subsection{Regional setting}

The Black Sea is a semi-enclosed basin which is connected to the Mediterranean via the Bosporus strait and to the Sea of Azov via the Kerch strait. Several important European rivers (Danube, Don, Dniper, Dniestr, Bug) discharge large amount of freshwater into the Black Sea, making it a typical "estuarine" basin (Bakan and Büyükgüngör, 2000; Stanev, 2005). Circulation in the Black Sea is controlled by the discharge of this freshwater and the inflow of a smaller volume of salty water via the narrow Bosporus strait. This inflow leads to a distinct stratification of the water column characterized by low salinity surface waters in the upper $100 \mathrm{~m}$ that outflows to the Mediterranean Sea. Exchange between this lighter water mass and the denser, saltier deep waters coming in from the Mediterranean via the Bosporus strait is limited. This results in the world's largest anoxic basin.

Modeling studies show that wind forcing controls the cyclonic, coast-parallel general circulation of the Black Sea (see Stanev, 2005, and references therein). Two cyclonic gyre-systems dominate the basin, while a series of smaller cyclonic and anti-cyclonic gyres characterize the basin at a mesoscale (Bakan and Büyükgüngör, 2000; Stanev, 2005). 


\section{Materials and methods}

Eight piston cores collected during the BLASON 2 (Lericolais, 2002) and ASSEMBLAGE 1 (Lericolais and Assemblage Partners, 2004) cruises were analysed in the framework of the ASSEMBLAGE project (Tab. 1, Fig. 2). For this study, we selected the upper part of each core that includes the last deglacial period (Tab. 1). Core B2 KS02 is located on the shelf at the Bosporus outlet; cores B2 KS24 and MD04 2773 are located on the Romanian shelf in a coastal environment; cores B2 KS33 and MD04 2762 were retrieved from the deep basin and the remaining three cores (B2 KS38, MD04 2770 and MD04 2754) are from the western and northwestern slopes (Fig. 3).

The spacing of samples taken from these cores varies from $10 \mathrm{~cm}$ in the light and dark micro-laminated sediments and in the sapropel layer to $10-20 \mathrm{~cm}$ in lutites. Additional samples were taken close to lithological and biostratigraphic boundaries in order to improve the resolution (see Tab. 2 for details).

In addition, we studied the modern calcareous nannoplankton assemblage, and investigated dissolution effects in the water column so that we can better interpret the signal recorded in the sediment. For this purpose, six water samples collected with Niskin bottles (MD04 2757, 65, 74, 76, 90, 93) and five interface samples collected with an IFREMER interface coring system (MD04 2757, 65, 69, 75, 76) during the ASSEMBLAGE 1 cruise were used (Tab. 1, Fig. 2).

\subsection{Lithological units}

Our samples show that in the western Black Sea, the lithology varies conspicuously from the shelf to the slope (Fig. 3). The most significant differences occur between deep cores and shelf cores that do not show lamination or other visible structures (B2 KS02, B2 KS24 and MD04 2773).

In cores B2 KS24 and MD04 2773, Unit 3 is structureless except for the presence of silty-sand intercalations and iron sulfide black spots. A characteristic ravinement deposit occurs, between 45 and $66 \mathrm{~cm}$ in core B2 KS24, and between 45 and $99 \mathrm{~cm}$ in core MD04 2773. It comprises silty sand rich in debris of Dreissena and freshwater mollusks, also referred to as a "hash layer" in the literature (Ryan et al., 1997; Ballard et al., 2000; Major et al., 2002; Ryan et al., 2003; Lericolais et al., 2006). In this setting, the Unit 3 upper boundary has a sharp contact with the upper unit and falls always at the base of the "hash" layer (sensu Major et al., 2002). Above this boundary, we observed a unit containing frequent mollusks such as the bivalves Mytilus, Modiolus, Cardium and Dreissena, together with some gastropods (the "Shallow Unit" of Fig. 3). Therefore, it is impossible to recognize Units 2 and 1 of Ross and Degens (1974) in this setting.

Core B2 KS02 is homogeneous; thus the lithologic units of Ross and Degens (1974) are not recognizable. However, radiocarbon dating shows that the age of the core bottom is younger than the boundary between Units 3 and 2, suggesting that sedimentation rates on the western shelf are high.

Units 3 to 1 are clearly distinguishable in the slope and basinal cores even if more diversified sedimentological features can be observed Specifically, Unit 3 of cores MD04 2754, MD04 2770, B2 KS38 located on the slope consists of almost homogeneous mud, whereby core MD04 2770 is marked by iron sulfide black spots and core B2 KS38 has silty-sand intercalations.

Grey mud with thin dark laminae characterizes Unit 2 in cores MD04 2754 and B2 KS38 while a low contrast lamination occurs in core MD04 2770. All three cores show white micro-laminae at the bottom. Moreover, there is a thin dark grey mud interval at the bottom of Unit 2 in core MD04 2754 (the "transition interval" of Fig. 3).

Unit 1 (the youngest) consists of grey mud with thin, white laminae in cores MD04 2754 (with intercalations of dark laminae at the bottom) and B2 KS38. The white laminae are absent in core MD04 2770, instead laminated, dark, olive grey mud occurs.

In the basinal setting, Unit 3 of core B2 KS33 is laminated in the lower part and structureless in the upper part. The transition from Unit 3 to Unit 2 is marked by the same transitional interval as observed in core MD04 2754 on the slope. Unit 2 itself comprises thin dark lamina. Unit 1 is only centimetres in thickness and is made up of white laminae.

Core MD04 2762, also from the deep basin, consists of slump deposit from 500 to $260 \mathrm{~cm}$ core depth and homogenite deposits from $215 \mathrm{~cm}$ to the core-top (Bourget, 2006). However, also in this core, the thin autochthonous sediment intervals show sedimentological features related to the Units 3, 2 and 1 of Ross and Degens (1974) (Fig. 3).

Our core description underscores the problems involved in the recognition of Units 1-3 of Ross and Degens (1974) in different bathymetric settings, as well as the need to introduce additional units for a characterization of Black Sea sediments. To summarize, Unit 3 is the only unit recognizable across different bathymetric settings. Unit 2 is distinguishable in slope and deep basin cores, while in the shelf cores, it corresponds to a shell hash layer overlain by a mud layer rich in Mytilus (Ryan et al., 1997; 2003; Major et al., 2002; Ballard et al., 2000; 
Lericolais et al., 2006). Unit 1 occurs only in some basin and slope cores, but not in shelf cores which in addition shows a high sedimentological variability.

\subsection{Core sediment samples}

For calcareous nannoplankton analysis of core samples, smear slides of bulk sediment (to retain the original composition of the assemblage) were mounted with Norland Optical Adhesive. A semi-quantitative analysis was performed with an optical microscope at 1250X magnification, whereby 6 abundance classes were distinguishing based on the following criteria:

$0=$ absent

$1=$ very rare (1-10 specimens every 150 field of view)

2 = rare (1-3 specimens every 3-4 field of view)

$3=$ common (3-15 specimens every field of view)

$4=$ frequent $(15-30$ specimens per field of view)

$5=$ very abundant $(>30$ specimens per field of view)

Additional counts in a fixed area corresponding to 62.5 fields of view were performed for the very rare species Braarudosphaera bigelowii. The counts were converted into population density (number/mm²) using the following formula:

Class $=$ number of individuals observed/field of view number* field of view area $\left(0.0314 \mathrm{~mm}^{2}\right)($ See Tab. 2)

Although this method is merely semi-quantitative, it allows an estimate of the vertical distribution of the population density of E. huxleyi.

\subsection{Water samples and recent sediments}

1.5 liters of each water sample collected with Niskin bottles were sieved at $32 \mu \mathrm{m}$ and washed with buffered water. Fecal pellets and other organic aggregates which could contain coccoliths were carefully disaggregated using a small brush. The $<32 \mu \mathrm{m}$ fraction was separated by filtering (Millipore HA filters, $47 \mathrm{~mm}$ diameter, 0.45 $\mu \mathrm{m}$ pore size) using a low pressure to ensure a homogeneous distribution of the material on the filter (Giunta, 2001). The filters were dried in an oven at $40^{\circ} \mathrm{C}$ for at least 12 hours and then placed in appropriate dishes. The same preparation technique was used for interface samples, which were resuspended, subsampled with a precision micro-pipette (1 ml of resuspension) and diluted in $300 \mathrm{ml}$ buffered water before filtration (Andruleit, 1996, modified). Slides for optical microscopy were prepared by cutting a segment of each filter, making it transparent with a drop of immersion oil, and covering it with a cover-glass.

Coccoliths and coccospheres were counted separately. Specifically, whenever possible, we counted 500 coccoliths and a fixed area of $4 \mathrm{~mm} \times 10 \mathrm{~mm}$ for coccospheres.

Results obtained from Niskin bottle samples were converted into cells/liter using the equation:

Cells/liter $=($ specimens*filtered area $) /($ counted area*filtered volume $)$.

\section{Age estimation}

The timeframe of our biostratigraphic study was established using 17 AMS ${ }^{14} \mathrm{C}$ age determinations on four selected cores (Tab. 3). The age of the boundaries between the intervals recognized were determined by direct ${ }^{14} \mathrm{C}$ dating or by averaging the linearly interpolated ages between two consecutive ${ }^{14} \mathrm{C}$ dates (i.e., assuming a constant sedimentation rate between the age control points). The ages of 3,330 yrs B.P. for the boundary between the lithological Units 1 and 2 and 7,160 yrs B.P. for the boundary Unit 2/Unit 3 (Jones and Gagnon, 1994) served as additional time markers. For interpolation, the mass flow deposits identified in core MD04 2762 by sedimentological analyses ( $X$ ray radioscopy, granulometry, gamma densimetry and petrography; Bourget, 2006) were omitted from the sedimentary record.

The AMS ${ }^{14} \mathrm{C}$ analyses were carried out in the radiocarbon laboratories in Poznam, Gif sur Yvette (Saclay) and Kiel. The samples used were well-preserved shells of mollusks from the cores (Tab. 3). All data are reported in radiocarbon years; corrections for the mean apparent age of the surface sea water have not been made. 


\section{Results}

\subsection{Calcareous nannoplankton in sediment cores}

In all the cores studied, three different intervals, all with very low biodiversity, can be recognized using the abundance of calcareous nannoplankton (Tab. 2, Figs. 4 and 5). Starting from the bottom, interval 3 is characterized by the absence of $B$. bigelowii, the very rare and spotty occurrence of $E$. huxleyi, as well as abundant siliciclastic detritus and Cretaceous and Cenozoic reworked species. While B. bigelowii is always absent in this ecozone except for a single sample from core B2 KS02 (at $580 \mathrm{~cm}$ ) and two samples from core MD04 $2773(223$ and $130 \mathrm{~cm}), E$. huxleyi is present in almost all the cores, although it is generally very rare and scattered (Tab. 2).

Compared to interval 3 , interval 2 is characterized by a higher content of $E$. huxleyi (maximum 800 specimens $/ \mathrm{mm}^{2}$ ) (Plate 1, c), the presence of $B$. bigelowii (maximum 20 specimens $/ \mathrm{mm}^{2}$ ), and a slightly lower abundance of Cretaceous and Cenozoic reworked species. These characteristics apply to all the cores studied, except the deepest core B2 KS33 for which B. bigelowii is absent and E. huxleyi is scattered throughout the interval.

Interval 1 (the uppermost) is characterized by the presence of abundant and very well-preserved Holocene species, but it has very low biodiversity and few Cretaceous and Cenozoic reworked forms. The nannoplankton assemblage is largely dominated by E. huxleyi (up to 1600 specimens $/ \mathrm{mm}^{2}$ ) (Fig. 4, Plate 1, a, b). Except at the top of core MD04 2754, B. bigelowii, although much lower in abundance (maximum of $13.4 \mathrm{specimens} / \mathrm{mm}^{2}$ ), is always present (Fig. 5, Plate 1, a).

Rare but well-preserved specimens of Gephyrocapsa oceanica occur in core B2 KS33 at 90, 80 and $40 \mathrm{~cm}$ core depth, as well as in core MD04 2762 scattered in the interval $300-140 \mathrm{~cm}$. Small individuals occur also at the top of core MD04 2773.

Finally, rare, very small and thin forms of Syracosphaera lamina were observed in cores B2 KS38 (only at 5 and $0 \mathrm{~cm}$ ), B2 KS33 (at $0 \mathrm{~cm}$ ), as well as more continuously in interval 1 and interval 2 (at 220 and $200 \mathrm{~cm}$ ) of core MD04 2762.

In addition to calcareous nannoplankton, we observed the constant presence of diatom frustules and fragments in cores B2 KS02 and MD04 2762, and their discontinuous occurrence in cores MD04 2754 (at 205-190, 92, 80 and $52 \mathrm{~cm}$ ), B2 KS38 (at 280-140, 120-90 and $40 \mathrm{~cm}$ ), and MD04 2770 (at 64 and $24 \mathrm{~cm}$ ). In cores B2 KS24 and B2 KS33, siliceous microfossils are absent. Diatoms, together with radiolarian fragments and frequent sponge spiculae, occur in the upper part of interval 2 and in interval 1 of core MD04 2773.

Noteworthy is the occurrence, reported here the first time, of a layer rich in carbonate acicular crystals in the two cores on the Romanian shelf (at $70 \mathrm{~cm}$ in core MD04 2773, and at $36 \mathrm{~cm}$ in core B2 KS24) (Plate1, d).

In almost all cores (with the exception of B2 KS24, MD 2773 and B2 KS33), we observed the presence near the top of interval 3 of peculiar layers rich in aragonite rice-grains and siliceous fragments, but devoid of calcareous nannoplankton (Figs. 3 and 4; Plate 1, e, f). In core MD04 2773, of aragonite-like crystals of a lower abundance occur at 320, 300 and $240 \mathrm{~cm}$. The interference colors are identical to the other aragonite-rich layers, but these crystals do not show the same rice-grain form. For this reason, we do not consider this level to be equivalent to that characterizing the other cores.

\subsection{Calcareous nannoplankton in water samples}

Quantitative analyses carried out on six Niskin bottle water samples show a dominance of the species E. huxleyi at all sites (Tab. 4, Fig. 6, Plate 1, g) and the presence, albeit in much lower abundances, of S. lamina (Plate 1, h) except at site MD04 2774 where coccospheres are absent. Specifically, the abundance of E. huxleyi coccospheres is highest at site MD04 2793, with values of about $1100 \times 10^{3}$ cells/liter, while at core sites MD04 2790 and MD04 2776, it is $155 \times 10^{3}$ and $27.1 \times 10^{3}$ cells/liter respectively. The lowest abundance is encountered near the Bosporus strait (MD04 2757; $3.7 \times 10^{3}$ cells/liter) and at the center of the basin (MD04 2765; $5.1 \times 10^{3}$ cells/liter).

Like E. huxleyi, coccospheres of S. lamina are most abundant at site MD04 2793 (about $51.7 \times 10^{3}$ cells/liter). Lower abundances are encountered at sites MD04 $2790\left(5.4 \times 10^{3}\right.$ cells/liter), MD04 2765 (about $3 \times 10^{3}$ cells/liter) and MD04 $2757\left(1.5 \times 10^{3}\right.$ cells/liter), while the lowest value $\left(0.9 \times 10^{3}\right.$ cells/liter $)$ occurs at site MD04 2776. The same trend is registered for coccoliths of both E. huxleyi and S. lamina (Tab. 4).

Site MD04 2774 in front of the mouth of the River Danube is almost devoid of coccolithosphaerae. The abundances of coccoliths, small diatoms and silicoflagellate fragments are low, while that of terrigenous and organic material are high.

Finally, only one occurrence of the coccolith of B. bigelowii was observed, namelyat site MD04 2793. 


\subsection{Calcareous nannoplankton in Recent sediments}

At five of the six water samples stations studied (MD04 2757, 2765, 2769, 2775, 2776), sediment samples at the water-sediment interface were also collected. All of them show a very high abundance of E. huxleyi (Tab. 5). S. lamina is rare at site MD04 2765 and is absent in all other samples studied, while B. bigelowii is absent at sites MD04 2757 and 2769, and is rare at the other three sites (Tab. 5). Fragments of silicoflagellates and diatoms are always present in low abundance, except for site MD04 2775, where they are absent.

\section{Discussions}

\subsection{Biostratigraphic ecozones versus lithological units}

The intervals described in section 4.1 are based on the abundance of the calcareous nannoplankton assemblage. Variations in the abundance and composition of this assemblage allows bioevents to be defined. These events are clearly traceable throughout the basin, and are closely related to paleoceanographic changes in the Black Sea through time. For this reason, these intervals may be interpreted as ecozones. As the boundaries between our ecozones are AMS ${ }^{14} \mathrm{C}$ dated, each ecozone corresponds to a well-defined time interval.

A comparison between the observed lithological units as defined by Ross and Degens (1974) and the ecozones described here shows that, while lithological units cannot be traced throughout the basin, calcareous nannoplankton ecozones can be recognized in all the cores studied despite local sedimentological variations (Tab. 6). Moreover, the lithological boundary between Units 3 and 2 always pre-date the biostratigraphic boundary (Tab. 6), probably because colonization of the new habitat by calcareous nannoplankton is gradual.

In the deeper cores, with the exception of B2 KS33, the sedimentological boundary between Units 2 and 1 always coincides with an ecozone boundary. In core B2 KS33, the lithological boundary occurs slightly above the biostratigraphic boundary, suggesting that at this site the first coccolithophorid blooms were too weak to produce white laminae in the sediment.

The peculiar layer composed of rice-grained aragonite-rich laminae (Plate 1, e, f) in the upper part of Ecozone 3 (see also Ross and Degens, 1974; Hay et al., 1991; Arthur and Dean, 1998) was dated at 7,450 yrs B.P. (Jones and Gagnon, 1994). Our work suggests that this level can play an important role in correlations both because of its basin-wide distribution and its potential for assessing the hydrological evolution of the Black Sea basin. Linear interpolation of our ${ }^{14} \mathrm{C}$ dates gave ages of the layer of aragonite-rich laminae ranging from 6,148 yrs B.P. (core MD04 2770) to 6,924 yrs B.P. (core MD04 2762). Because sampling was done at $10 \mathrm{~cm}$ intervals, different aragonite micro-laminae were sampled from one core to another, hence the difference in ${ }^{14} \mathrm{C}$ ages. More detailed studies on these micro-laminae are needed to ascertain whether they were formed during a single synchronous event coeval throughout the entire basin.

In any case, the result of our analyses combined with AMS dating allows assessing the sedimentary rate throughout the basin. The computed sedimentation rate of Ecozone 2 shows a very high variability (4.4 - 248 $\mathrm{cm} / \mathrm{kyr}$; Tab. 6).

\subsection{Salinity implications}

Calcareous nannoplankton, whenever present, is always well-preserved, although the limited number of species and at times also of specimens suggests the presence of restricted marine conditions. Bukry et al. (1970) and Bukry (1974) first used calcareous nannoplankton as a paleosalinity indicator for paleoceanographic studies in the Black Sea. They showed that $E$. huxleyi is the species most tolerant of salinity variations (11-41\%o). Thus, its absence in Ecozone 3 supports the hypothesis of fresh-water lacustrine conditions in the basin until 7,160 yrs B.P. (Fig. 7). This ecozone corresponds to the dark, laminated, lutite sediments of Ross and Degens (1974), and is characterized by rare but regular presence of small E. huxleyi specimens in almost all cores (Fig. 4, Tab. 2). This surprising observation suggests two hypotheses:

(1) E. huxleyi specimens found in Ecozone 3 are reworked and are derived from marine sediment outcrops of previous sea level highstands, probably the Eemian (isotope stage 5e), since small outcrops of this age have already been reported (see references in Yanko, 1990). For this hypothesis, it is unclear why only this fragile form (E. huxleyi) was reworked and no other coeval forms were observed;

(2) The E. huxleyi specimens observed are in situ and are derived from the passive transport of tiny placoliths of this species from the Mediterranean to the Black Sea during short term connection events. The extremely rare abundance and the small size suggest that the reproduction of $E$. huxleyi took place in a sub-optimal environment. Studies detecting small placoliths colonizing Portuguese coastal lagoons after short term connections with the Atlantic Ocean support this hypothesis (M. Cachao, pers. comm. 2005). 
Since B. bigelowii is absent in Ecozone 3 and this species cannot survive at salinities lower than 17 \%o (Bukry et al., 1970; Bukry, 1974), we suggest that the presence of E. huxleyi implies a salinity between 11 and $17 \%$. We conclude therefore that during the last glacial, the Black Sea never became a real "fresh-water lake", in contrast to conclusions of most sedimentological analyses reported in the literature. Although diluted, some salty water could have remained from earlier (including the last) interglacial connections of the Black Sea basin to the Mediterranean, allowing $E$. huxleyi to survive albeit in very low abundances. This is consistent with the deep sill model of Major et al. (2002), which presumes that during the period 12,800 - 7,160 years B.P., inflow of marine Mediterranean waters started to mix with the fresh-brackish waters of the Black Sea, thereby increasing the salinity.

The rare but continuous presence of $E$. huxleyi together with the first appearance of $B$. bigelowii pinpoints the beginning of Ecozone 2 as well as a slow salinity increase in the basin. This co-occurrence suggests a salinity of at least 17\%o (Bukry et al., 1970; Bukry, 1974), but our limited knowledge on the ecological preferences of $B$. bigelowii and the absence of laboratory cultures, as reported in Negri and Giunta (2001), do not allow an estimation of the precise salinity range for this species. Nevertheless, since the Black Sea reached its modern marine but low salinity conditions 3,300 yrs B.P. (lower boundary of the Ecozone 1), the top ward increase in $B$. bigelowii recorded in the Ecozone 2 in most of the cores (B2KS02, B2KS24, B2KS38, MD04 2773 and MD04 2770) suggests a gradual salinity increase.

The E. huxleyi colonization of the Black Sea (Ecozone 1) clearly marks the beginning of more stable marine conditions with a salinity similar to its modern values (22-29\%o, Paavola et al., 2005) (Fig. 7). Analysis of the calcareous nannoplankton content in water samples in fact shows abundant $E$. huxleyi as we expected and as the interface-sediment record reflects. In this ecozone, a distinct negative punctual shift of $E$. huxleyi abundance together with a decrease in $B$. bigelowii is recorded in cores with high sedimentation rates and a more complete Ecozone 1 (cores MD04 2754 and 2770). This trend suggests a change in the physico-chemical parameters during the Upper Holocene that could be related to a climatic event characterized by enhanced precipitation and runoff. In contrast, the decreasing abundance of E. huxleyi observed in Ecozone 1 of core MD04 2762 could be related to homogenite deposition in which significant dilution by siliciclastics occurred.

\subsection{Evolution of the Black Sea during Recent time}

Although plankton samples presents, in contrast to sediment samples, only a snapshot and is therefore of limited significance, we used qualitative data from them to compare the distribution of the species in time and quantitative data to highlight differences in the modern distribution of coccolithophores in the basin.

Water samples at core station MD04 2774 in front of the mouth of the Danube are marked by the absence of coccospheres (Fig. 6), a high abundance of terrigenous and organic material, together with few diatoms and silicoflagellates fragments, suggesting high turbidity as a result of turbulence (related to river discharge) in the water column. Farther away from the mouth of the Danube, the calcareous nannoplankton abundance increases to a maximum because of fluvially-induced nutrient enrichment (sites MD04 2793 and MD04 2790) (Fig. 6). Intermediate abundances are observed at sites MD04 2776 and MD04 2765 in the center of the basin and where influence of the Danube river plume is small, while the lowest abundance occurs at the station close to the Bosporus strait (MD04 2757) (Fig. 6). In addition, surface sediments below these stations indicate that the delicate Syracosphaera lamina present in water samples is absent at the seafloor, thus suggesting dissolution and/or dilution throughout the water column. In fact, although $E$. huxleyi experiences large blooms and thus can be transferred rapidly to the bottom by zooplankton fecal pellets, S. lamina only develops sporadically, so that its liths are dispersed singly and are dissolved before reaching the bottom. This is true in spite of a slightly higher resistance of Syracosphaera spp. to dissolution effects compared to E. huxleyi (Roth and Berger, 1975; Roth and Coulbourn, 1982).

Another interesting feature is the near absence of $B$. bigelowii in water samples. This species is present in all cores, but is absent except for very rare occurrences in three surficial samples (MD04 2765, 75, 76) and one water sample (MD04 2793) not far from the Danube river plume. The continuous presence of this species in older sediment of all cores studied suggests that during the past 7,160 years, Braarudosphaera encountered in the Black Sea conditions to survive and to reproduce, albeit in abundances that are not comparable to that of the pentaliths found in the geological record of the Atlantic ocean (e.g., Paleo-Alampay et al., 1999; Kelly et al., 2003). However, the past several dozen years witnessed changes that resulted in its near disappearance in the water column. Dramatic shifts in phytoplankton species composition occurred following the construction of the Iron Gate dams across the Danube River in the early 1970s. In particular, Humborg et al. (1997) and Osawa et al. (2005) observed changes in the silicon-to-nitrogen ratio of the Black Sea nutrient load with a reduction by about two thirds in dissolved silicate, causing changes in the phytoplankton community. Likewise, Lancelot et al. (2002) observed a decrease in silicate and an increase in phosphate and nitrate that resulted in higher primary 
production rates in the summer, with a clear shift from siliceous (diatoms) to non-siliceous (dinoflagellate, calcareous nannoplankton etc.) taxa. The annual E. huxleyi bloom in the Black Sea between May and July may be considered part of a phytoplankton succession (Oguz and Merico, 2006). Coming after the diatom and dinoflagellate blooms under nitrogen-depleted and moderate light conditions, E. huxleyi seems to be able to make use of regenerated nutrients available in the surface mixed layer (Oguz and Merico, 2006). We suggest, however, that Braaurodosphaera is unable to exploit these resources, and that the changes in nutrient supply resulting from recent dam constructions could have affected the already oligotrophic calcareous nannoplankton assemblage, restricting the rare $B$. bigelowii to areas that are under the influence of the Danube River plume and depleting it completely far from this nutrient source.

\section{Conclusions}

We conclude from our study that:

- Three ecozones, recognizable in all basin and shelf cores despite large sediment facies changes, were defined using a detailed calcareous nannoplankton analysis. The lowermost ecozone is characterized by the rare presence of small specimens of E. huxleyi (Ecozone 3). The second is marked by the first invasion of the nannoplankton species E. huxleyi and the deposition of sapropels sediments (Ecozone 2). The most recent ecozone is defined by a dominance of E. huxleyi (Ecozone 1). These ecozones testify to three important phases of basin evolution.

- Low assemblage diversity combined with the ecological preferences of the calcareous nannoplankton species identified allow the paleosalinity variations of the basinal water masses to be inferred. The Black Sea passed from fresh-to-brackish waters to low-salinity marine conditions.

- The multi-laminae aragonite level in the upper part of Ecozone 3 provides a useful means for basin-wide correlations.

A comparison of the modern assemblages in the water column and in surface sediments with the fossil record shows clear diagenetic effects on and ecological changes in the coccolithophore assemblage:

- S. lamina is less abundant than E. huxleyi in surface water samples, and is absent in deeper water and in sediments, suggesting dissolution on its way through the water column.

- $B$. bigelowii is present in all cores, but is almost absent in the water column and in some of the recent sediments. This suggests a change in water conditions most probably related to variations in nutrient content in the last few decades as a result of dam construction across the Danube River in the early 1970's.

\section{Acknowledgments}

This paper is a contribution of the ASSEMBLAGE project funded by the European Commission (EVK3-CT-200200090). We thank the crews of the research vessels Le Suroit and Marion Dufresne for assistance during the Blason 2 and the Assemblage 1 cruises. The technical assistance of Paolo Ferrieri during SEM analyzes is gratefully acknowledged. The AMS 14C age determinations were carried out in Gif-sur-Yvette/Saclay, Poznan \&

Kiel. In this connection, our thanks go to M.Paterne, E.Cottereau, T. Goslar, P.Grootes and MJ Nadeau. Finally, we thank $\mathrm{M}$. Cachao and $\mathrm{H}$. Andruleit for their useful comments and suggestions made on the manuscript and H.K. Wong for basic help to improve our English.

\section{Taxonomic appendix}

Emiliania huxleyi (Lohmann, 1902) Hay \& Mohler, in Hay et al. 1967

Braarudosphaera bigelowii (Gran \& Braarud, 1935) Deflandre 1947

Syracosphaera lamina Lecal-Schlauder 1951

Gephyrocapsa oceanica Kamptner 1943 


\section{References}

Andruleit H., 1996. A filtration technique for quantitative studies of coccoliths. Micropaleontology 42 (4), 403-406.

Arthur, A.M., Dean, W.E., 1998. Organic-matter production and preservation and evolution of anoxia in the Holocene Black Sea. Paleoceanography 13 (4), 395-411.

Arthur, A.M., Dean, W.E., Neff, E.D., Hay, B.J., Jones, G.A., King, J., 1994. Late Holocene (0-2000 y BP) organic carbon accumulation in the Black Sea, Glob. Biogeochem. Cycl. 8, 195-217.

Ballard, R.D., Coleman, D.F., Rosenberg G., 2000. Further evidence of abrupt Holocene drowning of the Black Sea shelf. Mar. Geol. 170 (3-4), 253-261.

Bakan, G., Büyükgüngör, H., 2000. The Black Sea. Mar. Pollut. Bull. 41 (1-6), 24-43.

Bourget, J., 2006, Le bassin occidental de la mer Noire au Quaternaire Terminal; variabilité des forçages externes sur la sédimentation en domaine profond [Master 2 recherche ENVOLH thesis]: Université de Bordeaux 1, $31 \mathrm{pp}$.

Bukry, D., 1974. Coccoliths as paleosalinity indicators - evidence from Black Sea. In: Degens, E.T., Ross, D.A., (Eds.), The Black Sea - Geology, Chemistry and Biology. Mem. Am. Assoc. Pet. Geol. 20, 353-363.

Bukry, D., King, A.S., Horn, M.K., Manheim, F.T., 1970. Geological significance of coccoliths in fine-grained carbonate bands of postglacial Black Sea sediments. Nature 26 (5241), 156-158.

Giunta S., 2001. I coccolitoforidi ed i loro derivati geochimi (Alkenoni): un valido strumento per l'interpretazione paleoclimatica e paleoceanografica degli ultimi 18.000 anni (Mediterraneo centro-orientale e Oceano Indiano). Unpublished PhD Thesis, Bologna University. 119 pp.

Görür, N., Çagatay, M.N., Emre, Ö., Alpar, B., Sakinç, M., Islamoglu, Y., Algan, O., Erkal, T., Keçer, M., Akkök, R., Karlik, G., 2001. Is the abrupt drowning of the Black Sea shelf at 7,150 yr BP a myth? Mar. Geol. 176, 65-73.

Hay, B. J., Arthur, A.M., Dean, W.E, Neff, E.D., Honjo, S., 1991. Sediment deposition in the Late Holocene abyssal Black Sea with climatic and chronological implications. Deep-Sea Res. 38, S1211-S1235.

Humborg, C., Ittekkot, V., Cociasu, A., v. Bodungen, B., 1997. Effect of Danube dam on Black Sea biogeochemistry and ecosystem structure. Nature 386, 385-388.

Jones, G.A., Gagnon, A.R., 1994. Radiocarbon chronology of Black Sea sediments. Deep-Sea Res. 41 (3), $531-$ 557.

Kelly, D.C., Norris, R.D., Zachos, J.C., 2003. Deciphering the paleoceanographic signficance of early Oligocene Braarudosphaera chalk in the South Atlantic. Mar. Micropaleontol. 49, 49-63.

Lancelot, C., Staneva, J., Van Eeckhout, D., Beckers, J.-M., Stanev, E., 2002. Modelling the Danube-influenced north-western continental shelf of the Black Sea. II: Ecosystem response to changes in nutrient delivery by the Danube River after its damming in 1972. Estuar., Cost. Shelf Sci. 54, 473-499.

Lericolais, G., Popescu, I., Guichard, F., Popescu, S. M., Manolakakis, L., 2006. Water-level fluctuations in the Black Sea since the Last Glacial Maximum. In: Yanko-Hombach, V., Gilbert, A. S., Panin, N., Dolukhanov, P. M., (Eds.), The Black Sea Flood Question: Changes in Coastline, Climate, and Human Settlement, 437-452.

Lericolais, G., and Assemblage partners, 2004, Assemblage deliverable 9a: MD139-Assemblage 1 cruise report (http://www.ifremer.fr/assemblage/d9a-assemblage1-report.htm): European Community, Energy, Environment and Sustainable Development, Deliverables of the EVK3-CT-2002-00090 European project; Lericolais, G.; 97.

Lericolais, G., 2002, BLASON 2 cruise report (available at http://www.ifremer.fr/sismer/catal/campagne/campagne.htql?crno=2020070).

Major, C., Ryan, W., Lericolais, G., Hajdas, I., 2002. Constraints on Black Sea outflow to the Sea of Marmara during the last glacial-interglacial transition. Mar. Geol. 190, 19-34.

Negri, A., Giunta, S., 2001. Calcareous nannofossil paleoecology in the sapropel S1 of the eastern Ionian sea: paleoceanographic implications. Palaeogeogr., Palaeoclimatol., Palaeoecol. 169, 101-112.

Oguz, T., Merico, A., 2006. Factors controlling the summer Emiliania huxleyi bloom in the Black Sea: A modeling study. J. Mar. Syst. 59 (3-4), 173-188.

Osawa, M., Takahashi, K., Hay, B.L., 2005. Shell-bearing plankton fluxes in the central Black Sea, 1989-1991. Deep Sea Res. 52, 1677-1698.

Paavola, M., Olenin, S., Leppakoski, E., 2005. Are invasive species most successful in habitats of low native species richness across European brackish water seas? Estuar., Coast. Shelf Sci. 64, 738-750.

Paleo-Alampay, A.M., Mead, G.A., Wei, W., 1999. Unusual Oligocene Braarudosphaera-rich layer of the South Atlantic and their paleoceanographic implications. J. Nannoplankton Res. 21 (1), 17-26.

Pilskaln, C.H., Pike, J., 2001. Formation of Holocene sedimentary laminae in the Black Sea and the role of benthic flocculent layer. Paleoceanography 16 (1), 1-19. 
Ross, D.A., Degens, E.T., 1974. Recent sediments of Black Sea. In: Degens, E.T., Ross, D.A., (Eds.), The Black Sea - Geology, Chemistry and Biology. Mem. Am. Assoc. Pet. Geol. 20, 183-199.

Ross, D.A., Degens, E.T., Macllvain, J., 1970. Black Sea: recent sediment history. Nature 170, 163-165.

Roth, P. H., Berger, W.H., 1975. Distribution and dissolution of coccoliths in the south and central Pacific. In: Dissolution of Deep-Sea Carbonates. Cushm. Found. Foram. Res., Spec. Publ. 13, 87-113.

Roth, P. H., Coulbourn, W. T., 1982. Floral and solution patterns of coccoliths in surface sediments of the North Pacific. Mar. Micropal. 7, 1-52.

Ryan, W.B.F., Pitman III, W.C., Major, C.O., Shimkus, K., Moskalenko, V., Jones, G.A., Dimitrov, P., Gorür, N, Sakinç, M., Yüce, H., 1997. An abrupt drowning of the Black Sea shelf. Mar. Geol. 138, 119-126.

Ryan, W. B.F., Major, C.O., Lericolais, G., Goldstein, S.L., 2003. Catastrophic flooding of the Black Sea. Annual Review of Earth Planet. Sci. 31, 525-554, (doi:10.1146/annurev.earth.31.100901.141249).

Stanev, E.V., 2005. Understanding Black Sea dynamics. An overview of recent numerical modeling. Oceanography 18 (2), 57-75.

Yanko, V., 1990. Stratigraphy and paleogeography of the marine Pleistocene and Holocene deposits of the southern sea of the USSR. Mem. Soc. Geol. It. 44, 167-187. 
Tab. 1 - Location of the study sites.

\begin{tabular}{|c|c|c|c|c|c|c|c|c|}
\hline Type & Station & Sampling method & Cruise & Phi (North) & $\mathrm{G}$ (East) & $\begin{array}{l}\text { Water } \\
\text { depth }(\mathrm{m})\end{array}$ & $\begin{array}{l}\text { Sediment } \\
\text { recovery }(\mathrm{m})\end{array}$ & $\begin{array}{l}\text { Studied cores } \\
\text { lenght }(\mathrm{cm})\end{array}$ \\
\hline Sediment core & B2 KS02 & Kullenberg & BLASON 2 & $41^{\circ} 29.734$ & $29^{\circ} 07.550$ & 88.8 & 9.07 & 907 \\
\hline Sediment core & MD04 2754 & Calypso & ASSEMBLAGE 1 & $41^{\circ} 59.23$ & $28^{\circ} 40.99$ & 453 & 32.17 & 300 \\
\hline Sediment core & MD04 2762 & Calypso & ASSEMBLAGE 1 & $42^{\circ} 38.870$ & $32^{\circ} 45.973$ & 2210 & 52.32 & 600 \\
\hline Sediment core & B2 KS33 & Kullenberg & BLASON 2 & $42^{\circ} 50.502$ & $32^{\circ} 35.962$ & 2173 & 3.03 & 96 \\
\hline Sediment core & MD04 2770 & Calypso & ASSEMBLAGE 1 & $44^{\circ} 12.80$ & $30^{\circ} 59.6$ & 358 & 41.82 & 300 \\
\hline Sediment core & B2 KS38 & Kullenberg & BLASON 2 & $43^{\circ} 48.424$ & $30^{\circ} 24.111$ & 355 & 9.31 & 280 \\
\hline Sediment core & B2 KS24 & Kullenberg & BLASON 2 & $43^{\circ} 53.792$ & $30^{\circ} 11.0$ & 96 & 3.98 & 178 \\
\hline Sediment core & MD04 2773 & Calypso & ASSEMBLAGE 1 & $44^{\circ} 37.160$ & $30^{\circ} 20.102$ & 68 & 3.63 & 300 \\
\hline Interface sample & MD04 2757-i & Ifremer ICS* & ASSEMBLAGE 1 & $42^{\circ} 29.989$ & $29^{\circ} 03.769$ & 1927 & & \\
\hline Interface sample & MD04 2765-i & Ifremer ICS* & ASSEMBLAGE 1 & $43^{\circ} 23.49$ & $30^{\circ} 30.99$ & 1608 & & \\
\hline Interface sample & MD04 2769-i & Ifremer ICS* & ASSEMBLAGE 1 & $44^{\circ} 14.19$ & $30^{\circ} 57.529$ & 206 & & \\
\hline Interface sample & MD04 2775-i & Ifremer ICS* & ASSEMBLAGE 1 & $44^{\circ} 57.45$ & $29^{\circ} 50.110$ & 30 & & \\
\hline Interface sample & MD04 2776-i & Ifremer ICS* & ASSEMBLAGE 1 & $43^{\circ} 18.979$ & $29^{\circ} 40.95$ & 1275 & & \\
\hline Water sample & MD04 2774 & Niskin bottles & ASSEMBLAGE 1 & $44^{\circ} 57.45$ & $29^{\circ} 50.110$ & 0 & & \\
\hline Water sample & MD04 2776 & Niskin bottles & ASSEMBLAGE 1 & $43^{\circ} 18.979$ & $29^{\circ} 40.95$ & 28 & & \\
\hline Water sample & MD04 2793 & Niskin bottles & ASSEMBLAGE 1 & $44^{\circ} 00$ & $29^{\circ} 54.00$ & 5 & & \\
\hline Water sample & MD04 2765 & Niskin bottles & ASSEMBLAGE 1 & $43^{\circ} 23.49$ & $30^{\circ} 30.99$ & 0 & & \\
\hline Water sample & MD04 2757 & Niskin bottles & ASSEMBLAGE 1 & $42^{\circ} 29.989$ & $29^{\circ} 03.769$ & 25 & & \\
\hline Water sample & MD04 2790 & Niskin bottles & ASSEMBLAGE 1 & $44^{\circ} 12.790$ & $30^{\circ} 59.61$ & 2 & & \\
\hline
\end{tabular}

*Ifremer Interface Coring System. 
Tab. 2 - Abundance of the calcareous nannoplankton species E. huxleyi (1) and B.

bigelowii (2) in the cores studied. Values are in num $/ \mathrm{mm}^{2}$. Shaded values correspond to Ecozone 1, bold values to Ecozone 2, and values in italics to Ecozone 3.

\begin{tabular}{|c|c|c|c|c|c|c|c|c|c|c|c|}
\hline \multicolumn{3}{|c|}{ B2 KS02 } & \multicolumn{3}{|c|}{ MD04 2754} & \multicolumn{3}{|c|}{ MD04 2762} & \multicolumn{3}{|c|}{ B2 KS33 } \\
\hline $\begin{array}{l}\text { depth } \\
\text { (cmbsf) }\end{array}$ & (1) & (2) & $\begin{array}{l}\text { depth } \\
\text { (cmbsf) }\end{array}$ & (1) & (2) & $\begin{array}{l}\text { depth } \\
\text { (cmbsf) }\end{array}$ & (1) & (2) & $\begin{array}{l}\text { depth } \\
\text { (cmbsf) }\end{array}$ & (1) & (2) \\
\hline 0 & 1592.36 & 0.25 & 0 & 1592.36 & 0.00 & 0 & 1592.36 & 2.73 & 0 & 1592.36 & 5.71 \\
\hline 20 & 15.92 & 0.99 & 11 & 1592.36 & 1.23 & 5 & 1592.36 & 2.23 & 5 & 1592.36 & 4.46 \\
\hline 40 & 15.92 & 0.25 & 20 & 1592.36 & 2.47 & 10 & 1592.36 & 1.49 & 10 & 15.92 & 0.00 \\
\hline 60 & 238.85 & 0.50 & 32 & 1592.36 & 1.23 & 15 & 1592.36 & 2.98 & 15 & 15.92 & 0.00 \\
\hline 80 & 238.85 & 1.49 & 40 & 1592.36 & 1.85 & 20 & 1592.36 & 2.73 & 20 & 0.00 & 0.00 \\
\hline 100 & 1.06 & 0.00 & 52 & 1592.36 & 1.85 & 25 & 1592.36 & 0.74 & 30 & 0.00 & 0.00 \\
\hline 120 & 0.00 & 0.00 & 60 & 1592.36 & 1.85 & 30 & 1592.36 & 0.00 & 40 & 1.06 & 0.00 \\
\hline 140 & 0.00 & 0.00 & 72 & 796.18 & 0.00 & 40 & 796.18 & 1.24 & 50 & 0.00 & 0.00 \\
\hline 160 & 0.00 & 0.00 & 80 & 1592.36 & 0.62 & 45 & 238.85 & 1.74 & 60 & 0.00 & 0.00 \\
\hline 180 & 0.00 & 0.00 & 92 & 1592.36 & 2.47 & 50 & 238.85 & 1.49 & 70 & 0.00 & 0.00 \\
\hline 200 & 0.00 & 0.00 & 100 & 15.92 & 0.62 & 60 & 517.52 & 0.74 & 80 & 0.00 & 0.00 \\
\hline 220 & 1.06 & 0.00 & 112 & 1.06 & 1.23 & 70 & 796.18 & 1.49 & 90 & 0.00 & 0.00 \\
\hline 240 & 1.06 & 0.00 & 120 & 1.06 & 1.23 & 80 & 796.18 & 2.48 & & & \\
\hline 260 & 1.06 & 0.00 & 132 & 238.85 & 3.09 & 90 & 796.18 & 0.99 & & & \\
\hline 280 & 0.00 & 0.00 & 140 & 0.00 & 1.23 & 100 & 517.52 & 0.99 & & & \\
\hline 300 & 0.00 & 0.00 & 150 & 1.06 & 1.85 & 110 & 796.18 & 1.24 & & & \\
\hline 320 & 0.00 & 0.00 & 170 & 1.06 & 3.70 & 120 & 796.18 & 1.98 & & & \\
\hline 340 & 1.06 & 0.00 & 185 & 1.06 & 0.62 & 130 & 1592.36 & 3.22 & & & \\
\hline 360 & 0.00 & 0.00 & 190 & 1.06 & 4.94 & 140 & 1.06 & 0.25 & & & \\
\hline 380 & 0.00 & 0.00 & 195 & 1.06 & 0.00 & 150 & 238.85 & 0.25 & & & \\
\hline 400 & 0.00 & 0.00 & 205 & 0.00 & 2.47 & 160 & 0.00 & 0.25 & & & \\
\hline 430 & 0.00 & 0.00 & 215 & 1.06 & 0.62 & 170 & 127.39 & 1.24 & & & \\
\hline 480 & 0.00 & 0.00 & 225 & 0.00 & 0.00 & 180 & 15.92 & 0.74 & & & \\
\hline 530 & 0.00 & 0.00 & 235 & 1.06 & 0.00 & 190 & 1.06 & 0.50 & & & \\
\hline 580 & 0.00 & 0.25 & 245 & 1.06 & 0.00 & 200 & 1.06 & 0.50 & & & \\
\hline 630 & 1.06 & 0.00 & 250 & 0.00 & 0.00 & 210 & 1.06 & 0.99 & & & \\
\hline 680 & 1.06 & 0.00 & 300 & 0.00 & 0.00 & 220 & 0.00 & 3.47 & & & \\
\hline 730 & 0.00 & 0.00 & & & & 230 & 0.00 & 0.50 & & & \\
\hline 780 & 0.00 & 0.00 & & & & 240 & 0.00 & 3.47 & & & \\
\hline 828 & 0.00 & 0.00 & & & & 250 & 0.00 & 0.00 & & & \\
\hline 866 & 0.00 & 0.00 & & & & 255 & 0.00 & 0.00 & & & \\
\hline & & & & & & 265 & 0.00 & 6.95 & & & \\
\hline & & & & & & 275 & 0.00 & 3.97 & & & \\
\hline & & & & & & 285 & 0.00 & 8.43 & & & \\
\hline & & & & & & 295 & 0.00 & 0.74 & & & \\
\hline & & & & & & 305 & 1.06 & 0.99 & & & \\
\hline & & & & & & 323 & 0.00 & 0.00 & & & \\
\hline & & & & & & 343 & 0.00 & 1.49 & & & \\
\hline & & & & & & 363 & 0.00 & $*$ & & & \\
\hline & & & & & & 383 & 0.00 & 0.50 & & & \\
\hline & & & & & & 404 & 0.00 & 0.50 & & & \\
\hline & & & & & & 426 & 0.00 & $*$ & & & \\
\hline & & & & & & 444 & 0.00 & 0.50 & & & \\
\hline & & & & & & 465 & 0.00 & 0.74 & & & \\
\hline & & & & & & 482 & 1.06 & 0.00 & & & \\
\hline & & & & & & 484 & 15.92 & 0.00 & & & \\
\hline & & & & & & 497 & 1.06 & 0.00 & & & \\
\hline & & & & & & 507 & 0.00 & 0.00 & & & \\
\hline & & & & & & 514 & 1.06 & 0.00 & & & \\
\hline
\end{tabular}


Tab. 2

\begin{tabular}{|c|c|c|c|c|c|c|c|c|c|c|c|}
\hline \multicolumn{3}{|c|}{ MD04 2770} & \multicolumn{3}{|c|}{ B2 KS38 } & \multicolumn{3}{|c|}{ B2 KS24 } & \multicolumn{3}{|c|}{ MD04 2773} \\
\hline $\begin{array}{l}\text { depth } \\
\text { (cmbsf) }\end{array}$ & (1) & (2) & $\begin{array}{l}\text { depth } \\
\text { (cmbsf) }\end{array}$ & (1) & (2) & $\begin{array}{l}\text { depth } \\
\text { (cmbsf) }\end{array}$ & (1) & (2) & $\begin{array}{l}\text { depth } \\
\text { (cmbsf) }\end{array}$ & (1) & (2) \\
\hline 0 & 1592.36 & 5.56 & 0 & 1592.36 & 1.49 & 0 & 1592.36 & 0.99 & 0 & 1592.36 & 0.49 \\
\hline 9 & 238.85 & 2.47 & 5 & 1592.36 & 3.72 & 6 & 1592.36 & 13.39 & 5 & 1592.36 & 0.00 \\
\hline 24 & 1592.36 & 4.94 & 15 & 1592.36 & 8.43 & 16 & 796.18 & 3.97 & 10 & 1592.36 & 4.92 \\
\hline 34 & 1592.36 & 1.23 & 20 & 1592.36 & 4.22 & 26 & 238.85 & 0.50 & 20 & 1592.36 & 0.98 \\
\hline 44 & 1592.36 & 1.23 & 30 & 1592.36 & 4.96 & 36 & 1.06 & 0.00 & 30 & 238.85 & 17.23 \\
\hline 49 & 238.85 & 0.62 & 40 & 1592.36 & 1.24 & 46 & 238.85 & 0.25 & 40 & 15.92 & 8.37 \\
\hline 54 & 15.92 & 6.79 & 41 & 1592.36 & 8.68 & 56 & 15.92 & 0.00 & 55 & 238.85 & 6.40 \\
\hline 64 & 1.06 & 0.62 & 43 & 15.92 & 0.99 & 62 & 796.18 & 0.74 & 63 & 15.92 & 3.94 \\
\hline 74 & 796.18 & 1.23 & 50 & 15.92 & 4.22 & 65 & 15.92 & 0.00 & 70 & 15.92 & 0.49 \\
\hline 85 & 796.18 & 0.00 & 60 & 15.92 & 3.22 & 67 & 0.00 & 0.00 & 80 & 15.92 & 0.00 \\
\hline 95 & 0.00 & 0.00 & 70 & 15.92 & 19.84 & 72 & 1.06 & 0.25 & 90 & 1.06 & 0.00 \\
\hline 105 & 0.00 & 0.00 & 80 & 238.85 & 0.50 & 77 & 1.06 & 0.00 & 100 & 1.06 & 0.00 \\
\hline 110 & 0.00 & 0.00 & 90 & 238.85 & 0.99 & 79 & 0.00 & 0.00 & 110 & 1.06 & 0.00 \\
\hline 131 & 1.06 & 0.00 & 100 & 1.06 & 0.74 & 88 & 1.06 & 0.00 & 120 & 1.06 & 0.00 \\
\hline 144 & 1.06 & 0.00 & 110 & 1.06 & 0.00 & 98 & 1.06 & 0.00 & 130 & 15.92 & 0.49 \\
\hline 161 & 1.06 & 0.00 & 120 & 15.92 & 1.74 & 108 & 0.00 & 0.00 & 143 & 0.00 & 0.00 \\
\hline 171 & 1.06 & 0.00 & 130 & 0.00 & 0.00 & 118 & 15.92 & 0.00 & 163 & 0.00 & 0.00 \\
\hline 186 & 1.06 & 0.00 & 140 & 0.00 & 0.00 & 128 & 8.49 & 0.00 & 183 & 1.06 & 0.00 \\
\hline 236 & 0.00 & 0.00 & 150 & 0.00 & 0.00 & 138 & 15.92 & 0.00 & 203 & 1.06 & 0.00 \\
\hline \multirow[t]{12}{*}{286} & 1.06 & 0.62 & 160 & 0.00 & 0.00 & 148 & 0.00 & 0.00 & 223 & 1.06 & 0.49 \\
\hline & & & 170 & 1.06 & 0.00 & 158 & 1.06 & 0.00 & 243 & 1.06 & 0.00 \\
\hline & & & 180 & 15.92 & 0.00 & 168 & 1.06 & 0.00 & 263 & 0.00 & 0.00 \\
\hline & & & 190 & 1.06 & 0.00 & 178 & 1.06 & 0.00 & 283 & 0.00 & 0.00 \\
\hline & & & 200 & 0.00 & 0.00 & & & & 303 & 0.00 & 0.00 \\
\hline & & & 220 & 0.00 & 0.00 & & & & & & \\
\hline & & & 240 & 15.92 & 0.00 & & & & & & \\
\hline & & & 260 & 1.06 & 0.00 & & & & & & \\
\hline & & & 280 & 15.92 & 0.00 & \\
\hline & & & & & & \multicolumn{6}{|c|}{ Ecozone 2} \\
\hline & & & & & & & & Ecozo & & & \\
\hline & & & & & & & & $*$ pres & ut of tl & unted fixe & \\
\hline
\end{tabular}


Tab. 3 - Radiocarbon ages of mollusks in different cores and literature data from Jones and Gagnon (1994).

\begin{tabular}{|c|c|c|c|c|c|c|}
\hline Core & Depth (cm bsf) & Age ${ }^{14} \mathrm{C}$ BP & Source & Laboratory & Ref sample preparation & Ref datation \\
\hline B2KS24 & $4-6$ & $2820+/-30$ & Modiolus spp. & Poznan & & Poz-4068 \\
\hline B2KS24 & $20-22$ & $5525+/-35$ & Mytilus spp. & Poznan & & Poz-4067 \\
\hline B2KS24 & $40-41$ & $6520+/-40$ & Mytilus spp. & Poznan & & Poz-4065 \\
\hline B2KS24 & $51-53$ & $8620+/-50$ & Intact Dreissena spp. & Poznan & & Poz-4064 \\
\hline B2KS24 & $60-62$ & $8760+/-40$ & Broken Dreissena spp. & Poznan & & Poz-4063 \\
\hline B2KS24 & $110-111$ & $11,040+/-50$ & Broken valve of Didacna spp. & Poznan & & Poz-7870 \\
\hline B2KS24 & $133-134$ & $10,930+/-50$ & Shell & Poznan & & Poz-6536 \\
\hline B2KS24 & $134-135$ & $11,090+/-50$ & Cerastoderma spp. & Poznan & & Poz-7871 \\
\hline $\mathrm{B} 2 \mathrm{KS} 02$ & $875\left(846^{*}\right)$ & $6700+/-40$ & Small Gastropods & Poznan & & Poz-12679 \\
\hline B2KS-38 & 145 & $10,430+/-100$ & Dreissena spp. & Gif-Saclay & GIFA 40266 & SAC 1159 \\
\hline B2KS-38 & 172 & $10,670+/-60$ & Dreissena spp. & Gif-Saclay & GIFA 40267 & SAC 1160 \\
\hline B2KS-38 & 175 & $10,550+/-60$ & Dreissena spp. & Gif-Saclay & GIFA 40263 & SAC 1156 \\
\hline B2KS-38 & 198 & $10,640+/-60$ & Dreissena spp. & Gif-Saclay & GIFA 40270 & SAC 1163 \\
\hline B2KS-38 & 206 & $10,650+/-50$ & Shell & Poznan & & Poz-6535 \\
\hline B2KS-38 & 245 & $10,750+/-90$ & Dreissena spp. & Gif-Saclay & GIFA 40271 & SAC 1164 \\
\hline MD04 2770 & $520-521\left(256-257^{*}\right)$ & $10,590+/-50$ & Hydrobia spp. & Gif-Kiel & GIFA50039 & KIA28564 \\
\hline MD04 2770 & $520-521\left(256-257^{*}\right)$ & $10,510+/-40$ & Dreissena rostriformis & Gif-Kiel & GIFA50040 & KIA28565 \\
\hline \multicolumn{2}{|c|}{ Boundary between Units 1 and 2} & 3330 & Jones and Gagnon, 1994 & & & \\
\hline \multicolumn{2}{|c|}{ Boundary between Units 2 and 3} & 7160 & Jones and Gagnon, 1994 & & & \\
\hline
\end{tabular}

$(*)=$ corrected depth, (excluding core gaps).

Tab. 4 - Quantitative calcareous nannoplankton analysis of water samples (abundances in cells/liter).

\begin{tabular}{|c|c|c|c|c|c|c|}
\hline Sample and water depth & $\begin{array}{l}\text { E. huxleyi } \\
\text { (coccosphere) }\end{array}$ & $\begin{array}{l}\text { E. hwoleyi } \\
\text { (coccoliths) }\end{array}$ & $\begin{array}{l}\text { S. lamina } \\
\text { (coccosphere) }\end{array}$ & $\begin{array}{l}\text { S. lamina } \\
\text { (coccoliths) }\end{array}$ & $\begin{array}{l}\text { B. bigelowii } \\
\text { (coccosphere) }\end{array}$ & $\begin{array}{l}\text { B. bigelowii } \\
\text { (coccoliths) }\end{array}$ \\
\hline MD04 $27740 \mathrm{~m}$ & 0 & 0 & 0 & 0 & 0 & 0 \\
\hline MD04 $277628 \mathrm{~m}$ & $27.1 \times 10^{3}$ & $952 \times 10^{3}$ & $0.9 \times 10^{3}$ & $12.7 \times 10^{3}$ & 0 & 0 \\
\hline MD04 $27935 \mathrm{~m}$ & $1100 \times 10^{3}$ & $162.6 \times 10^{6}$ & $51.7 \times 10^{3}$ & $7900 \times 10^{3}$ & 0 & $*$ \\
\hline MD04 $27650 \mathrm{~m}$ & $5.1 \times 10^{3}$ & $460 \times 10^{3}$ & $2.9 \times 10^{3}$ & $117 \times 10^{3}$ & 0 & 0 \\
\hline MD04 $275725 \mathrm{~m}$ & $3.7 \times 10^{3}$ & $475 \times 10^{3}$ & $1.5 \times 10^{3}$ & $61.4 \times 10^{3}$ & 0 & 0 \\
\hline MD04 $27902 \mathrm{~m}$ & $155 \times 10^{\frac{1}{3}}$ & $1000 \times 10^{3}$ & $5.4 \times 10^{3}$ & $279 \times 10^{3}$ & 0 & 0 \\
\hline
\end{tabular}

*Presence of one snecimen in an extra-count area.

Tab. 5 - Qualitative calcareous nannoplankton analysis of surficial sediment samples.

Qualitative calcareous nannoplankton analysis of surficial sediment samples

\begin{tabular}{llll}
\hline Sample & E. huxleyi & S. lamina & B. bigelowii \\
\hline MD04 2757-i & Very abundant & Absent & Absent \\
MD04 2765-i & Very abundant & Rare & Present \\
MD04 2769-i & Very abundant & Absent & Absent \\
MD04 2775-i & Absent & Absent & Rare \\
MD04 2776-i & Very abundant & Absent & Present \\
\hline
\end{tabular}


Tab. 6 - Lithological boundaries, biostratigraphic boundaries and rice-grain aragonite-rich layer in the cores studied and their interpolated age.

\begin{tabular}{|c|c|c|c|c|c|c|c|c|}
\hline \multicolumn{9}{|c|}{ Biostratigraphic ecozones based on the abundance of calcareous nannofossils } \\
\hline Core & $\begin{array}{l}\text { Ecozone } 1 \\
\text { (cm bsf) }\end{array}$ & $\begin{array}{l}\text { Age of boundary } \\
1 / 2\end{array}$ & $\begin{array}{l}\text { Ecozone } 2 \\
\text { (cm bsf) }\end{array}$ & $\begin{array}{l}\text { Age of boundary } \\
2 / 3\end{array}$ & $\begin{array}{l}\text { Ecozone } 3 \\
\text { (cm bsf) }\end{array}$ & $\begin{array}{l}\text { Aragonite-rich } \\
\text { layer (cm bsf) }\end{array}$ & $\begin{array}{l}\text { Age of aragonite } \\
\text { level (yr B.P.) }\end{array}$ & $\begin{array}{l}\text { Sedimentation rate } \\
\text { of Ecozone } 2 \\
(\mathrm{~cm} / \mathrm{kyr})\end{array}$ \\
\hline $\mathrm{B} 2 \mathrm{KS} 02$ & $0-10$ & 3330 & $10-90$ & & $90-\ldots$ & $730 ; 828 ; 866$ & $\begin{array}{l}6232 ; 6627 ; \\
6781\end{array}$ & 248 \\
\hline MD04 2754 & $0-98$ & 3330 & $98-220$ & 6621 & $220-\ldots$ & 225 & 6755 & 37 \\
\hline MD04 2762 & $0-135$ & 3330 & $135-480$ & 7031 & $480-.$. & $449 ; 470$ & $6699 ; 6924$ & 17 \\
\hline B2KS 33 & $0-7$ & 3330 & $7-18$ & 5808 & $18-\ldots$ & & & 4.4 \\
\hline MD04 2770 & $0-47$ & 3330 & $47-86$ & 6148 & $86-\ldots$ & 86 & 6148 & 14 \\
\hline B2KS 38 & $0-42.5$ & 3330 & $42.5-125$ & 6474 & $125-\ldots$ & 130 & 6664 & 26 \\
\hline B2KS $24 *$ & $0-8$ & 3327 & $8-40.5$ & 6520 & $40.5-\ldots$ & & & 10 \\
\hline MD04 $2773^{*}$ & $0-25$ & 3330 & $25-45$ & & $85-\ldots$ & & & \\
\hline \multicolumn{9}{|c|}{ Lithological Units based on Ross and Degens (1974) } \\
\hline Core & $\begin{array}{l}\text { Unit } 1 \\
\text { (cm bsf) }\end{array}$ & $\begin{array}{l}\text { Age of boundary } \\
1 / 2\end{array}$ & $\begin{array}{l}\text { Unit } 2 \\
\text { (cm bsf) }\end{array}$ & $\begin{array}{l}\text { Age of boundary } \\
2 / 3\end{array}$ & $\begin{array}{l}\text { Unit } 3 \\
\text { (cm bsf) }\end{array}$ & $\begin{array}{l}\text { white lamina } \\
\text { (cm bsf) }\end{array}$ & $\begin{array}{l}\text { Age of aragonite } \\
\text { level (yr B.P.) }\end{array}$ & \\
\hline \multicolumn{9}{|l|}{$\mathrm{B} 2 \mathrm{KS} 02$} \\
\hline MD04 2754 & $0-98$ & 3330 & $98-240$ & 7160 & $240-\ldots$. & $222-236$ & $6575-7052$ & \\
\hline MD04 2762 & $0-135$ & 3330 & $135-492$ & 7160 & $492-\ldots$ & & & \\
\hline B2KS 33 & $0-1$ & 1562 & $1-24$ & 7160 & $24-\ldots$ & $\begin{array}{l}48-52.5 \\
59-64\end{array}$ & & \\
\hline MD04 2770 & & & $42-100$ & 7160 & $100-\ldots$ & $84-90$ & $5816-6220$ & \\
\hline B2KS 38 & $0-42.5$ & 3330 & $42.5-141.5$ & 7160 & $141.5-\ldots$ & $130-137$ & $6664-6931$ & \\
\hline $\mathrm{B} 2 \mathrm{KS} 24 *$ & & & & & $62-\ldots$. & & & $\begin{array}{l}* 45-66 \mathrm{~cm} \\
\text { hash layer }\end{array}$ \\
\hline MD04 $2773 *$ & & & & & $99-\ldots$ & & & $\begin{array}{l}* 45-99 \mathrm{~cm} \\
\text { hash layer }\end{array}$ \\
\hline
\end{tabular}




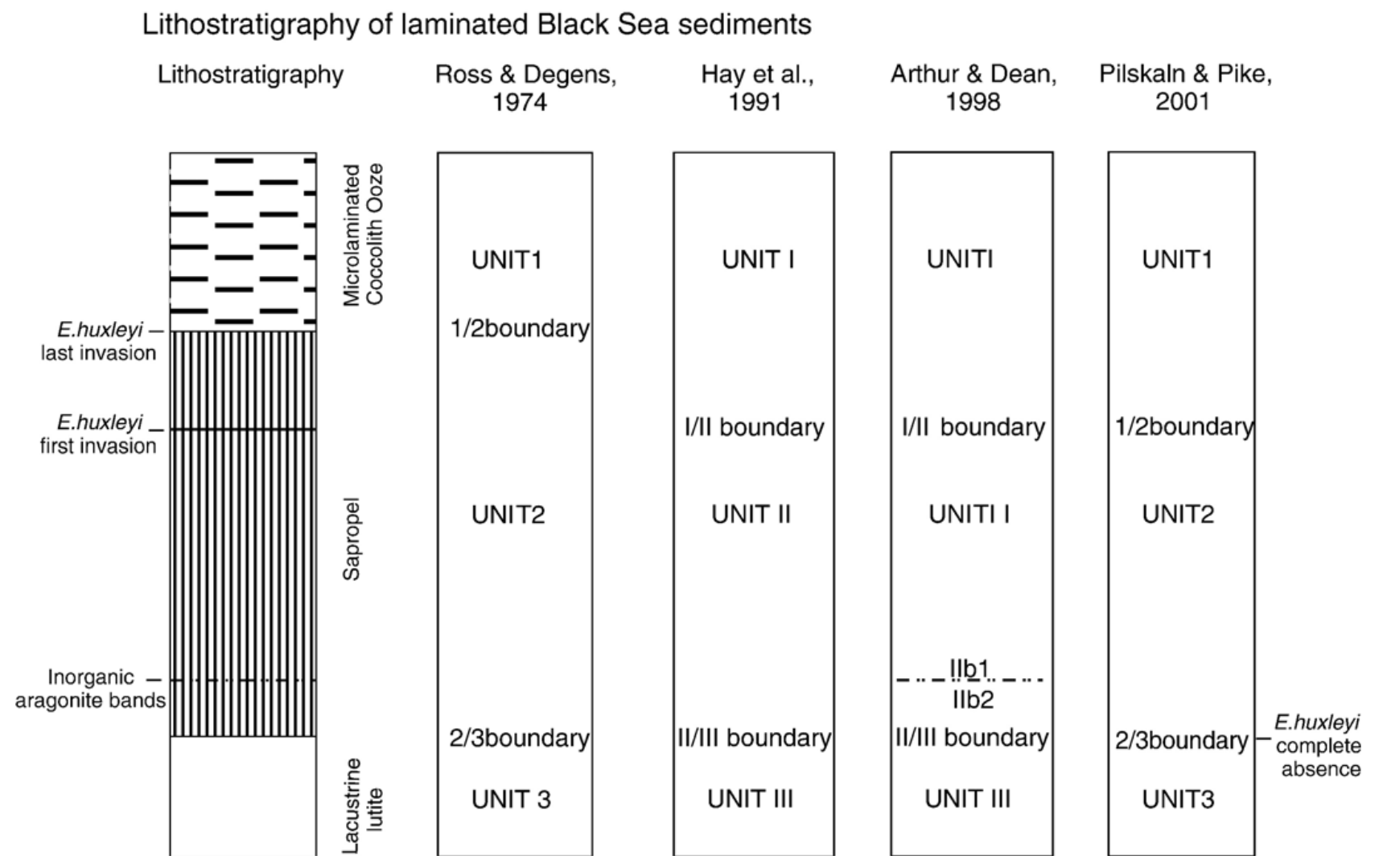

Fig. 1 - Comparison of different lithostratigraphic schemes for Holocene Black Sea sediments (Jones and Gagnon, 1994, modified). 


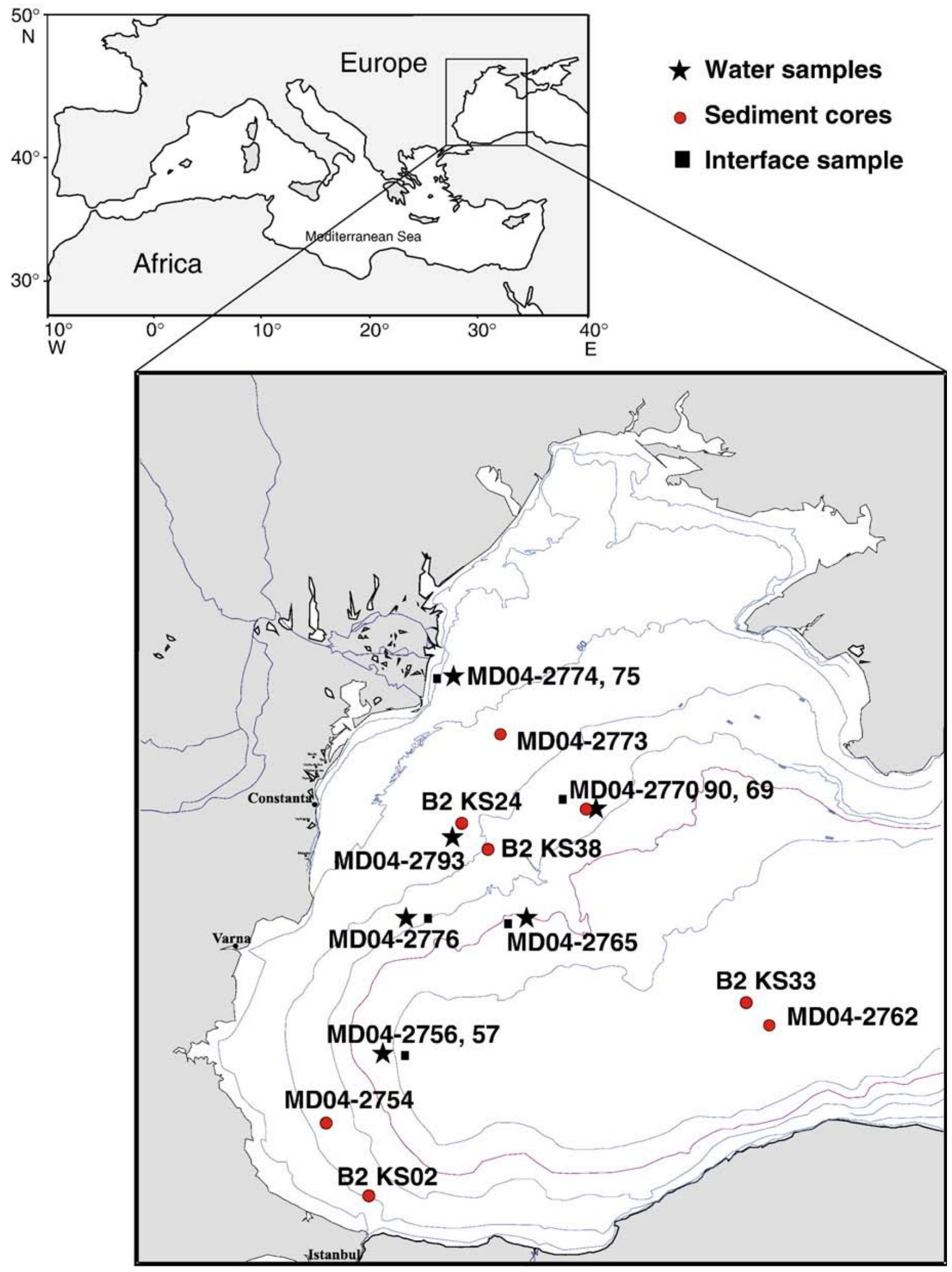

Fig. 2 - Location map of the sites studied. 

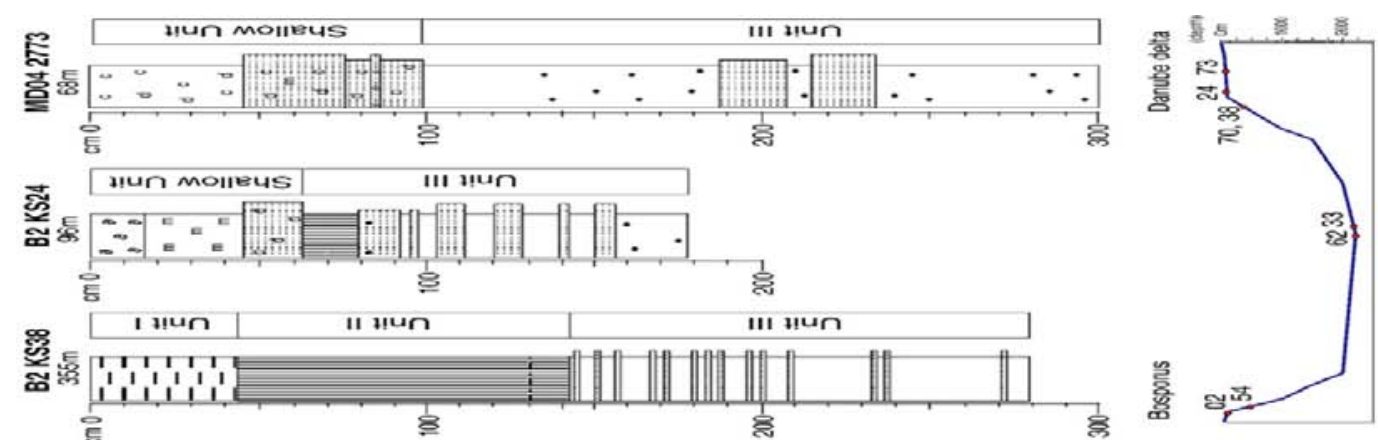

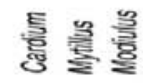

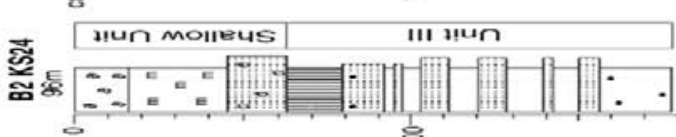

है है, है

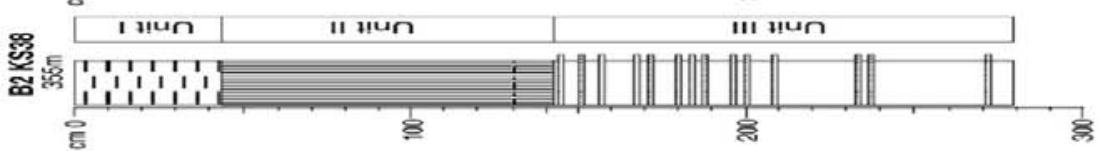

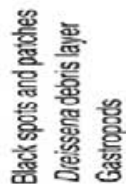

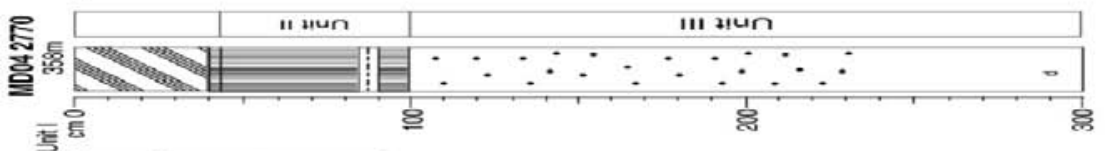

을

善黄 总

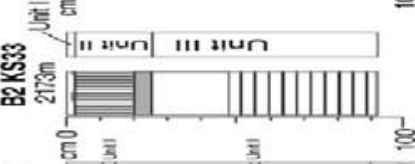
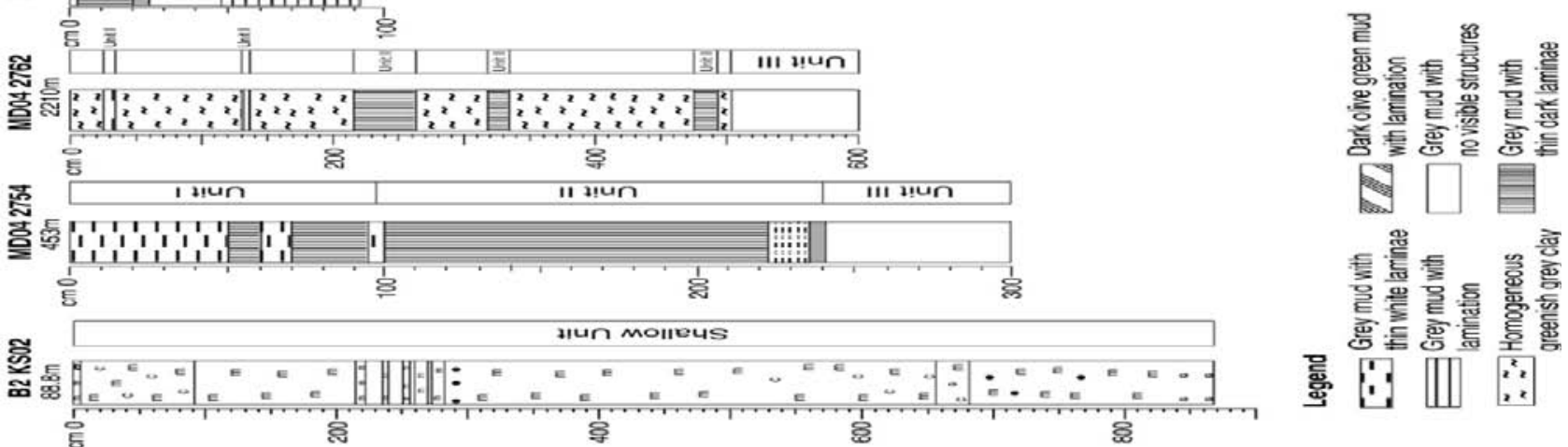

Fig. 3 - Lithologic logs of the cores studied and their locations on the basin profile.

Numbers in meters below the core designations are depths at the core stations The lithologic units are based on Ross et al. (1970).

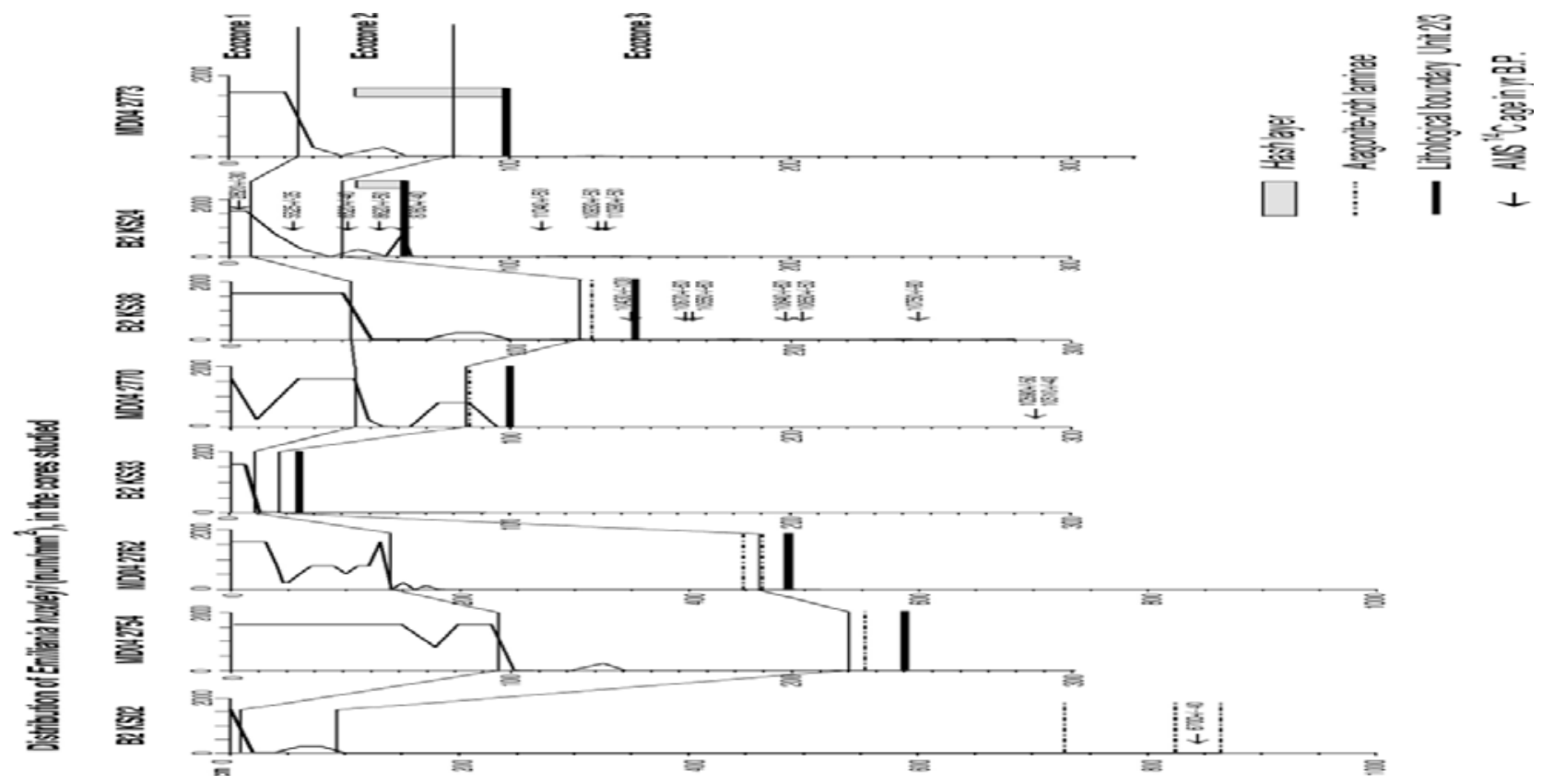

Fig. 4 - Distribution of the calcareous nannoplankton species E. huxleyi in the cores studied. The three ecozones are marked and correlated. Radiocarbon AMS dates are also given. 


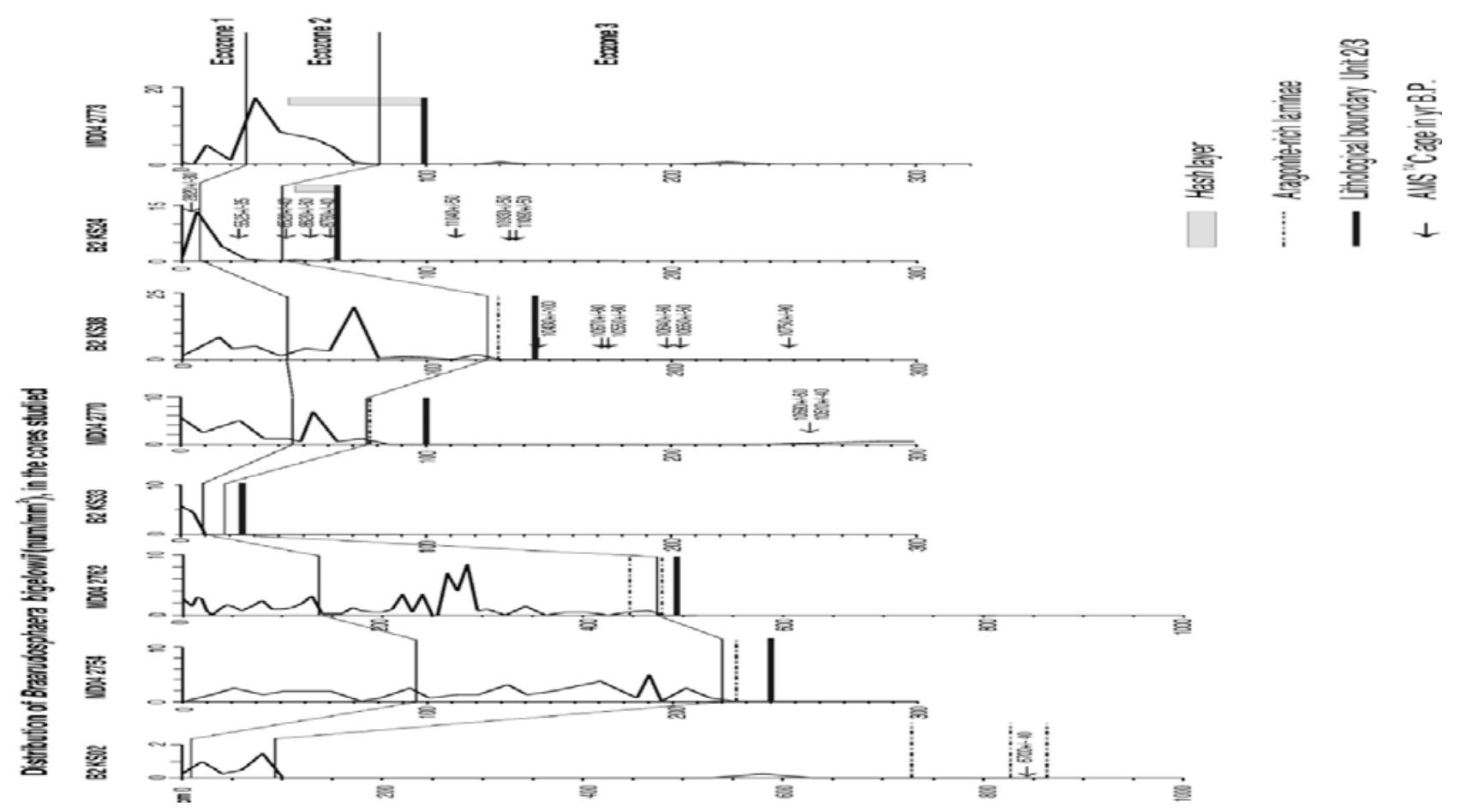

Fig. 5 - Distribution of the calcareous nannoplankton species B. bigelowii in the cores studied. The three ecozones are marked and correlated.

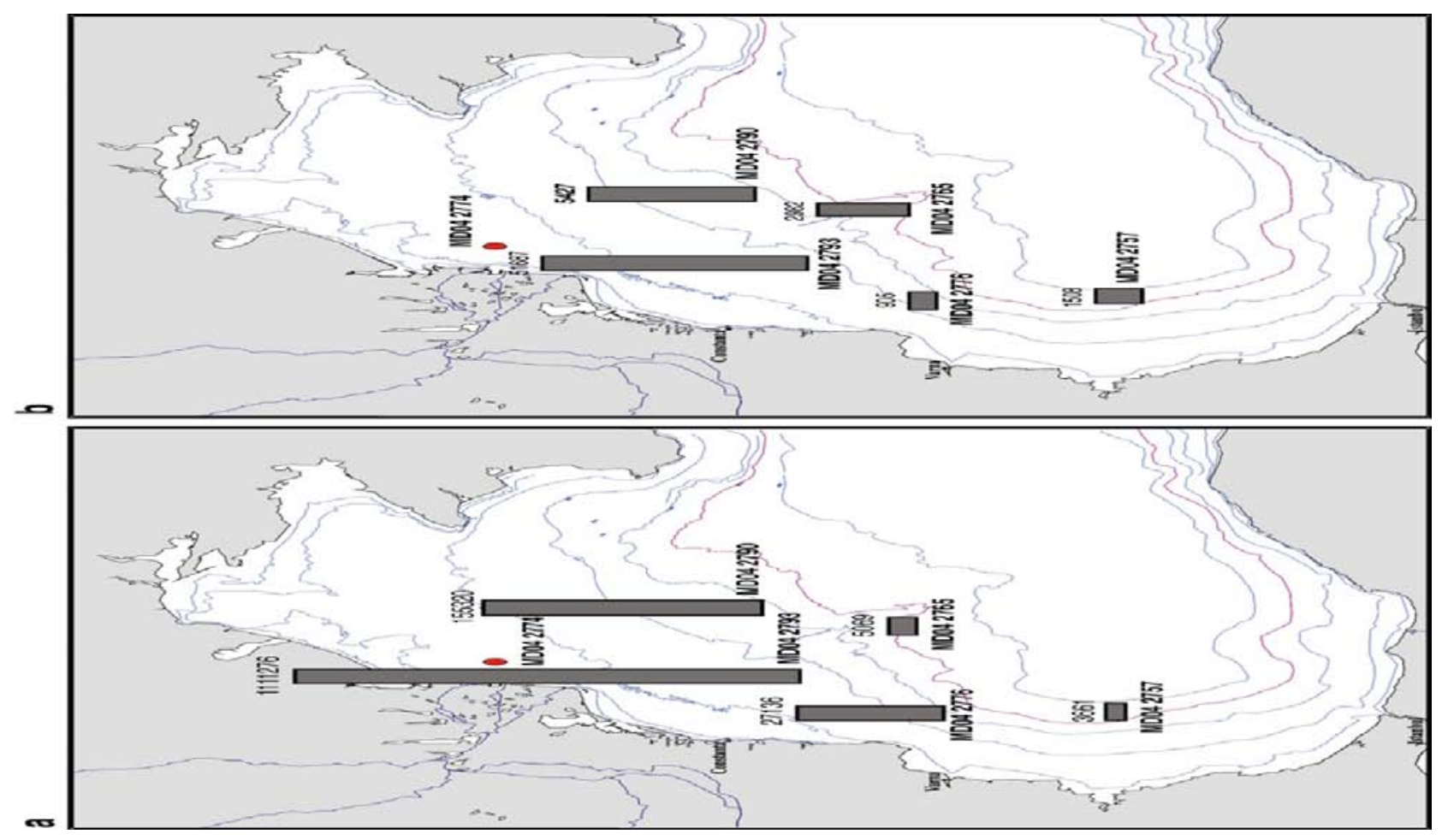

Fig. 6 - Abundance of E. huxleyi (a) and Syracosphaera spp. (b) coccospheres in Niskin bottle water samples (cell/liter). 
MD04 2754

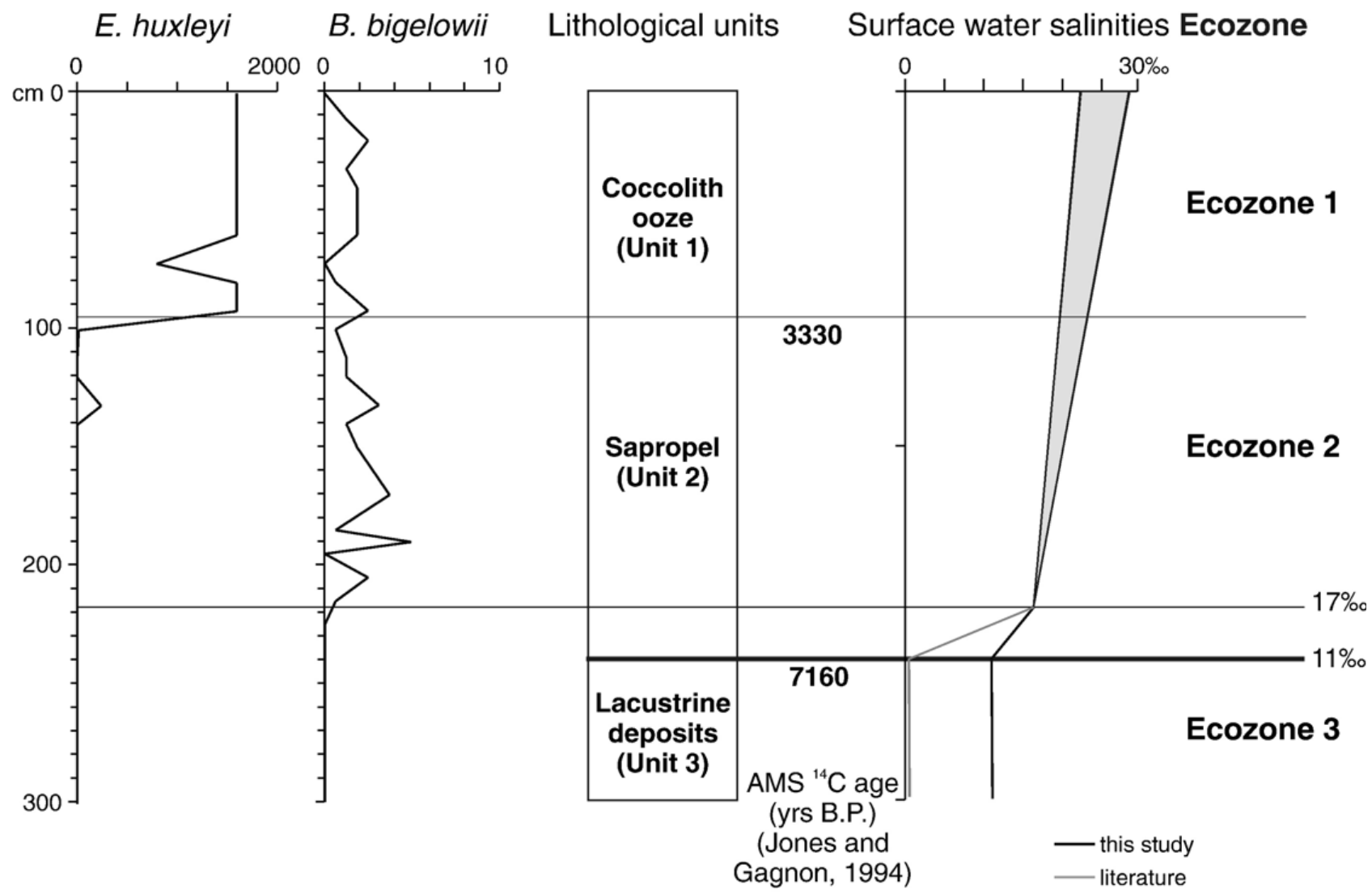

\begin{tabular}{lcccc}
\hline Comparison of occurrence of fossil Holocene coccoliths in marine areas of different salinity (Burky, 1974 modified) \\
\hline Emiliania huxleyi & $\begin{array}{c}\text { Sea of Azov } \\
(11 \%)\end{array}$ & $\begin{array}{c}\text { Black Sea } \\
(17-18 \%)\end{array}$ & $\begin{array}{c}\text { Atlantic Ocean } \\
(35 \% \circ)\end{array}$ & $\begin{array}{c}\text { Red Sea } \\
(37-41 \% \circ)\end{array}$ \\
\hline Braarudosphaera bigelowii & $\mathrm{X}$ & $\mathrm{X}$ & $\mathrm{X}$ & $\mathrm{X}$ \\
\hline
\end{tabular}

Fig. 7 - Salinity variations in the Black Sea during the past 9,000 yrs B.P.(from the literature and from our study). The biostratigraphic events are presented using core MD04 2754 because of its high sedimentation rate. Ecozonal boundary are represented by light lines, while the lithologic boundary between Units 2 and 3 is represented by a bold line. The grey band in the surface water salinities reconstruction is obtained considering the modern summer salinity values (22-29\%) reported by Paavola et al. (2005). 

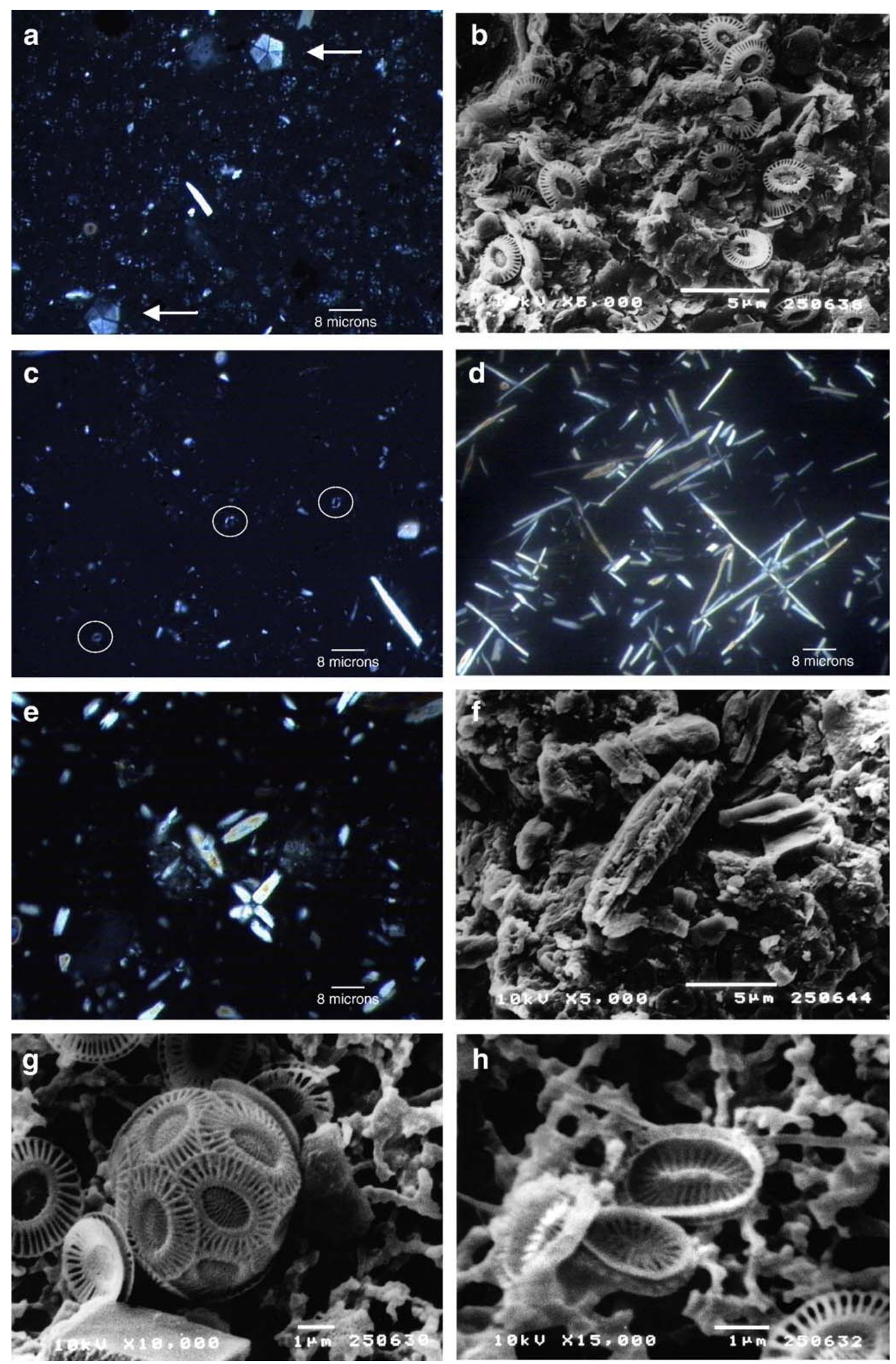

Plate 1 